\title{
THE DEVELOPMENT OF ISLAMIC DENTIST COMPETENCE IN DENTISTRY EDUCATION
}

\author{
Musri Amurwaningsih*, Titi Savitri Prihatiningsih**, Ika Dewi Ana*** \\ * Faculty of Dentistry, Sultan Agung Islamic University, Semarang - INDONESIA \\ ** Faculty of Medicine, Universitas Gadjah Mada, Yogyakarta - INDONESIA \\ *** Faculty of Dentistry, Universitas Gadjah Mada, Yogyakarta - INDONESIA
}

\begin{abstract}
Background: The subject of dental health care has been receiving a lot of attention from Moslems in Indonesia, especially its accordance with Al-Qur'an and Sunnah. It has encouraged numerous researches which corelate dental health care through Islamic perspective, and ignored the perspective of dentistry. Consequently, this research is aimed to develop, formulate and validate the competence of moslem dentists.

Method: Experts' agreement was develop using Delphi method. The result then was developed into an instrument with 2 criteria was used to determine content validity index (CVI) and content validity ratio (CVR). The result was developed into a 5-point Likert scale instrument which would be used to determine internal consistency (Cronbach's alpha) and corrected item-total correlation with Pearson's correlation.

Results: The qualitative method generated 4 domains. Domain shiddiq comprised 2 components, domain amanah 2 components, domain tabligh 2 components and domain fathonah 4 components with the value of agreement of each domain was approximately between $67 \%-100 \%$. The CVR value of the components of competence was between 0,69-1, while the CVI value was 0,877. The reliability test scored 0,923.

Conclusion: The Competence Standards of Islamic Dentistry can be used as guidance for designing Islamic dental curriculum. Further research should be conducted to design assessment.
\end{abstract}

Keywords: development of competencies, moslem, dentists, validation

\section{ABSTRAK}

Latar Belakang: Pelayananan kesehatan gigi menarik perhatian kaum muslim di Indonesia terutama terkait hukum perawatan gigi berdasarkan Al-Qur'an dan Sunnah. Hal ini mendorong banyaknya kajian tentang perawatan kesehatan gigi ditinjau dari sisi agama Islam tanpa memperhatikan sudut pandang ilmu kedokteran gigi. Penelitian ini bertujuan mengembangkan dan merumuskan kompetensi dokter gigi Islam, serta melakukan validasi kompetensi dokter gigi Islam. Metode: Kesepakatan pakar untuk mengembangkan standar kompetensi dilakukan dengan metode Delphi. Hasil yang diperoleh dikembangkan dengan 2 kriteria untuk mencari nilai content validity index (CVI) dan content validity ratio (CVR). Tahap selanjutnya menentukan internal consistency (koefisien Cronbach's alpha) dan corrected item-total correlation dengan korelasi Pearson dengan memberikan 5 skala Likert pada standar kompetensi.

Hasil: penelitian kualitiatif menghasilkan 4 domain dan 10 komponen kompetensi. Domain shiddiq 2 komponen, domain amanah 2 komponen, domain tabligh 2 komponen dan domain fathonah 4 komponen dengan nilai kesepakatan tiap komponen berkisar antara 67\% -100\%. Nilai CVR komponen komptensi antara 0,69-1, sedangkan nilai CVI sebesar 0,877. Uji reliabilias menghasilkan nilai 0,923.

Kesimpulan: Standar Kompetensi Kedokteran Gigi Islam dapat digunakan sebagai acuan pembuatan kurikulum kedokteran gigi Islam. Penelitian selanjutnya untuk merancang instrumen penilaian yang sesuai dengan indikator komponen kompetensi.

Kata kunci: pengembangan kompetensi, dokter gigi Islam, validasi

contact: musri@unissula.ac.id 


\section{INTRODUCTION}

Dental care attracts Muslims in Indonesia. Many Muslims question the law status of dental care according to Al-Qur'an and Sunnah. Society's questions related to the use of braces, dentures, tooth extraction while fasting, and the halal of the substances used in dental care bring out discussions about dental care seen from the religious side. However, these discussions only see it from the religious point of view, ignoring dentistry sciences, so there has been a lot of misinformation in the society.

The phenomenon described above is a big challenge for dentistry education institutions, especially the Islam-based ones in delivering dentistry education that is able to fulfill stakeholders' expectation, mainly Islamic alumni. An Islamic dentist is a dentist who has the character of a Muslim and understands Islamic values as a whole as well as is able to reflect Islamic values in his attitude. ${ }^{1}$ The aims of this study is to develop, formulate, and validate Islamic dentist competence.

\section{METHODS}

This study used the Delphi technique in 4 stages. The first stage was to identify the components of competence from experts by using an open-ended question questionnaire containing the question "What are the components of competence that an Islamic dentist must have and write the explanation of each component of competence?". The questionnaire was handed out to 10 respondents that were chosen by using purposive sampling method.

The second stage was to obtain an agreement. The questionnaire was given to experts to be assessed and given feedback for each component of competence with 3 criteria: accepted, accepted with changes, and rejected. Components of competence with an agreement score of $\geq 2 / 3$ (66\%) would be included in the standard competence. Components of competence with an agreement score of $\leq 1 / 3$ would not be included.
The third stage was to obtain the values of Content Validity Ratio (CVR) and Content Validity Index (CVI). The resulted framework of competence of stage 2 was developed by adding two assessment points ( $1=$ unimportant, $2=$ important $)$ as well as a column for the answer reasons. The questionnaire was handed out to 29 stakeholders that were chosen by using total sampling method. CVI calculation was only done on components with satisfactory CVR. ${ }^{2}$

In the fourth stage, a questionnaire with 5-point Likert scale $(1=$ strongly disagree, $2=$ disagree, $3=$ neither agree nor disagree, $4=$ agree, $5=$ strongly agree) was delivered to 50 practitioners fulfilling the inclusion criteria. This stage was to measure internal consistency and the relationship among components using Pearson's coefficient correlation. ${ }^{3}$

This study has obtained a permission from Komite Etik Penelitian Kedokteran dan Kesehatan, Faculty of Medicine, Universitas Gadjah Mada on February $23^{\text {rd }}, 2015$, No: KE/FK/223/EC.

\section{RESULTS AND DISCUSSION}

The first stage yielded 38 components of competence that later would be grouped into 6 domains, i.e.: aqidah, shiddiq, amanah, tabligh, fathonah, and dentistry sciences mastery. In the second stage, aqidah and dentistry sciences mastery domains were removed, so there were 4 domains left, i.e. shiddiq, amanah, tabligh, and fathonah. From 20 components of competence, 10 were rejected, 7 were accepted with changes, and 3 were accepted. The revised framework of standard competence by experts' agreement is presented in Table 1.

CVR calculation of each component of competence had values between $0.69-1$. These values were higher than CVR values in the table. This showed that all components of competence had good content validity, so it was acceptable. CVI value of 0.877 showed that Islamic dentist standard competence was acceptable 
Table 1. The framework of standard competence by experts' agreement

\section{Islamic Dentist Competence}

Domain I: Shiddiq/Honest

1. Working professionally with a feeling of always be observed by Allah SWT

2. Mastering sciences

Domain II: Amanah/Trustworthy

3. Holding amanah character firmly and being responsible

4. Having Islamic characters and attitude

\section{Domain III: Tabligh/Delivering}

5. Having the ability to develop many models of communication

6. Delivering the truth in everyday life

\section{Domain IV: Fathonah/Smart}

7. Working ethically according to Islam

8. Understanding the law of medical substances/materials

9. Performing Islamic dentistry actions

10. Conducting Islamic researches

Reliability test resulted Cronbach's alpha of 0.923 . The relationship among components was calculated using Pearson's correlation (Table 2). The r calculation yielded higher $r$ than table $r$. This meant that there was a positive correlation among components of competence.

Table 2. Distribution of components of competence

\begin{tabular}{|c|c|c|c|c|}
\hline Domain & $\begin{array}{c}\text { Number of valid } \\
\text { components }\end{array}$ & $\begin{array}{c}\text { Number of } \\
\text { eliminated } \\
\text { components }\end{array}$ & Validity & Coefficient \\
\hline Shiddiq & 2 & 0 & $0.674-0.691$ & \\
Amanah & 2 & 0 & $0.690-0.809$ & 0.923 \\
Tabligh & 2 & 0 & $0.696-0.791$ & \\
Fathonah & 4 & 0 & $0.830-0.861$ & \\
\hline
\end{tabular}

Competence is a complex attitude consisting of knowledge, skills, attitude, and personal competence. ${ }^{4}$ According to Wilkerson and Prihatiningsih, professional competence is a habit and policy in communication, knowledge, clinical skills, clinical reasoning, emotion, values and reflection in everyday practice to improve patients and society's health. ${ }^{5,6}$

According to Prihatiningsih, competence today does not only emphasize the mastery issue of a subject area, but also the performance of alumni, especially their professional behavior. ${ }^{5}$ Professional attitude and behavior is an important component of education contained within affective domain. Affective domain covers the aspects related to patients and professionalism, where it is covered holistically in Islamic values. This holistic approach brings doctors and patients closer to Allah, so that it will help patients to make the decisions related to their diseases and the recovering process. ${ }^{7,8}$ 
The results obtained 4 domains of Islamic dentist competence. This is in accordance with the concept of Muslim dentist attitude according to a study by Anggraini that mentioned that a Muslim dentist must have a noble akhlak (character) as set by Rasul's example, i.e. shiddiq, amanah, tabligh, and fathonah. ${ }^{9}$

The first domain is shiddiq which means "honest", words and deeds must be in line. A person with shiddiq character always feel observed by Allah, so that doctors would work honestly according to the prevailing standards as well as perform what is allowed (halal) and avoid what is prohibited (haram). A doctor believes that each action will be accounted for in front of Allah, the profession, and society. ${ }^{10,11}$

"With the conscience that we are always be observed by Allah, we will keep performing each act in earnest." (R.3.18)

The second component of competence is the mastery of sciences, either dentistry or Islamic values. Kasule said that integrated medical education curriculum should inculcate Islamic values in it. ${ }^{12}$

"Because nowadays there are a lot of information in the society about the laws of dental care, so dentists who are able to view it from dentistry side are needed to control the misinformation." (R.3.05)

Amanah means "trustworthy", everything that is entrusted will be done responsibly. ${ }^{13}$ Keeping all patient information confidential is an example of amanah in doctor-patient relationship. This is in line with the third component.

"A Muslim is amanah and responsible, different from a hypocrite who is treacherous and lying." (R.3.05)

Tabligh means "delivering", each Muslim has the obligation to deliver the truth to everyone. So is the case with a doctor who has the role to deliver the explanation of a disease, the treatment and therapy, adverse events of a drug, and other information related to a patient's condition. In this delivery, the doctor is responsible to ensure the patient to understand what has been delivered. ${ }^{14}$
Kasule said that a doctor has a social responsibility other than to treat patients. This condition allows a doctor to do dakwah to deliver the truth to patients and their family as well as to be the role model in society. ${ }^{8}$ This is in accordance with the sixth component of competence.

"Because dakwah is the obligation for each Muslim individual.” (R.3.1)

Doctor-patient communication skill must be mastered by doctors because the communication competence will determine the success of healthcare. In dentistry curriculum, developing effective doctor-patient communication has not been a priority, while in fact this skill is one of the main competence in Dentists Standard Competence. ${ }^{13,14}$ This is in line with the fifth component, the ability to develop various communication models as one of the competence in Islamic Dentists Standard Competence.

"...communication skill is very important for dentists to have, in relation to doctor-patient relationship." (R.3.05)

Fathonah means "smart", the ability to use the mind to determine or to differ what is right or wrong. ${ }^{9}$ This domain consist of 4 components of competence, they are work ethics according to Islam, the law of medical substances/materials, action in Islamic dentistry, and Islamic researches.

The limitation of this study was the small sample size, mainly in the first stage, so it would affect the number of collected components of competence. The results might be richer if more national experts were involved.

Authors suggested to do interviews to experts to enrich the study data and to dig deeper about the competence of a Muslim dentist. Authors also suggested to determine the indicator of each component of competence, so that the competence assessment instrument may be developed.

\section{CONCLUSION}

According to this study, authors conclude that the standard competence of Islamic dentist consists of 4 
domains and the 10 components of competence may be used as a reference of the development of Islamic dentistry curriculum.

\section{REFERENCES}

1. Nilasari V. Peran Dokter Muslim dalam Mengantisipasi Kemiskinan di Sektor Kesehatan. MIMBAR, 2009;25(1):79-88.

2. Azwar S. Reliabilitas dan Validitas $4^{\text {th }}$ edition. Yogyakarta: Pustaka Pelajar; 2013.

3. Fraenkel JK, Wallen NE, Hyun HH. How to design and evaluate reseach education. New York: Mc-Graw Hill Companies; 2012.

4. Carracio C, Wolfsthal SD, Englander R, Ferentz K, Martin C. Shifting Paradigms: From Flexner to Competencies. Academic Medicine, 2002;77(5).

5. Prihatiningsih TS. Perumusan Kompetensi Dokter di Indonesia. Jurnal Pendidikan KPKI, 2005;1(1):11-7.

6. Cohen RJ, Swerdilk ME. Psychological testing and assessment-an introduction to test and measurement. $7^{\text {th }}$ Ed. New York: McGraw-Hill Companies; 2009.

7. Hasan T, Noor H. Inculcating Islamic Input in The Curricula of Medical Science at Pre-clinical Years (Basic Medical Sciences). FIMA Year Book 2009:
Medical Education And Professional Ethics. Amman: Jordan Society for Islamic Medical Sciences; 2010.

8. Kasuel OH. Integrated Medical Education. Paper Presented at Workshop Universitas Yarsi; 2006. Accessed 15 Juni 2016 [ http://omarkasule-04. tripod.com]

9. Barnawi, Arifin M. Strategi $\mathcal{E}$ Kebijakan Pembelajaran Pendidikan Karakter. Yogyakarta: Ar-Ruzz Media; 2012.

10. Kasule $\mathrm{OH}$. A 13-years Experience of Integrating Islamic Values in the Medical Curriculum In SouthEast Asia. FIMA Year Book 2009: Medical Education And Professional Ethics. Amman: Jordan Society for Islamic Medical Sciences; 2010.

11. Showan AM. Character Building Melalui Pendidikan Agama Islam. Jurnal Episteme, 2015;10(1):176-98.

12. Anggraeni LD. Islamic dentist. Proceedings of International Tokushima Joint Meeting; 2013.

13. Kolegium Kedokteran Indonesia. Komunikasi Efektif Dokter-Pasien. Jakarta: Konsil Kedokteran Indonesia; 2006.

14. Konsil Kedokteran Indonesia. Standar Kompetensi Dokter Gigi KDGI). Jakarta: Konsil Kedokteran Indnesia; 2015. 